\title{
Haemodynamic effects of a new inotropic agent (dobutamine) in chronic cardiac failure
}

\author{
Jonas Beregovich, Christian Bianchi, Ralph D'Angelo, Ruth Diaz, and Shirley Rubler \\ From the Division of Cardiology, Department of Medicine, New York Medical College, New York City, U.S.A.
}

The haemodynamic effects of dobutamine were studied in 14 patients with chronic congestive cardiac failure. Heart rate, central venous, pulmonary arterial, pulmonary wedge, and aortic pressures, aortic dp/dt, cardiac output, cardiac index, stroke volume, and pulmonary and systemic vascular resistances were measured or derived. Dose-response curves were obtained by recording all measurements before and after intravenous infusion of dobutamine at rates of $2.5,5$, and $10 \mu \mathrm{g} / \mathrm{kg}$ per min for periods of 30 minutes each. Significant increases in mean values were observed for cardiac output from 3.7 to $6.4 \mathrm{l} / \mathrm{min}(82 \%)$, for stroke volume from 44 to $64 \mathrm{ml}(39 \%)$, and aortic dp/dt from 692 to $1414 \mathrm{mmHg} / \mathrm{s}(92.0$ to $188 . \mathrm{l} \mathrm{kPa} / \mathrm{s})(76 \%)$. Heart rate increased only moderately from 86 to IOI per minute $(31 \%)$. Significant reduction occurred in pulmonary wedge and central venous pressures. Mean aortic and pulmonary pressures did not change significantly, as a measure of decreased vascular resistances. The drug was uniformly well tolerated. The predominant inotropic effects of dobutamine without tachycardia or arrhythmias may be valuable in severe heart failure.

Catecholamines with predominant inotropic action have been used as an alternative to glycoside agents in conditions associated with cardiac failure. We have previously reported our experience with isoprenaline in myocardial infarction (Beregovich, Reicher-Reiss, and Grishman, 1972), and in the low cardiac output state following open heart surgery (Beregovich et al., 1971). The haemodynamic and renal effects of dopamine in patients with severe and chronic congestive heart failure have also been investigated (Beregovich et al., 1974; McDonald et al., I964; Rosenblum, Tai, and Lawson, 1970). These studies have demonstrated the effectiveness of such drugs as judged by clinical and haemodynamic criteria, provided their administration is based on a pharmacological understanding of their dose-response curves.

Dobutamine is a catecholamine, newly developed by systematic chemical substitutions of the side chains of isoprenaline and norepinephrine, which, in animal experiments, has proved to be almost exclusively an inotropic agent, with little direct action on the vessels. It also exhibits greatly reduced chronotropic and arrhythmogenic effects (Tuttle and Mills, in the press) (Fig. I).

This investigation was developed to study the dose-related effects of dobutamine in a group of

Received 15 November 1974 . patients with chronic congestive heart failure. Haemodynamic and renal parameters were measured during the administration of graded increments of the drug. The present report describes initial clinical observations with the use of this new inotropic agent.

\section{Subjects and methods}

Fourteen patients ( 8 men and 6 women) whose ages ranged from 24 to 74 years were investigated. All had cardiac failure secondary to myocardial, coronary, or valvular disease. Patients considered for this investigation received a complete verbal and written description of the procedure and of the potential effects of the drug to be administered. Consent was subsequently obtained in writing. The patients were allocated to 2 groups according to their functional class (New York Heart Association Classification) and cardiac index at the time of the study. Group A consists of 4 patients in functional class II, clinically 'compensated', and with a cardiac index more than $31 \mathrm{~min}^{-1} \mathrm{~m}^{-2}$ on basal conditions. Group B consists of to patients in functional class III or IV, with clinical evidence of severe congestive failure, and with a cardiac index less than $31 \mathrm{~min}^{-1} \mathrm{~m}^{-2}$. Digitalis, when previously administered, was discontinued 24 to 48 hours preceding the study. Standard haemodynamic techniques and instrumentation were used. Catheters were placed in the superior vena cava and pulmonary artery via antecubital vein cut-down or femoral 
vein puncture. An arterial catheter (No. $7 \mathrm{~F}$ polyethylene, $100 \mathrm{~cm}$ in length) was introduced percutaneously through one of the femoral arteries using Seldinger's technique (Seldinger, 1953).

Pressure curves were obtained with P23DB Statham transducers. Cardiac output determinations were carried out in duplicate by the dye dilution technique using indocyanine green. Aortic $\mathrm{dp} / \mathrm{dt}$ was recorded with a model RC-I differentiator. All tracings were recorded using a PR-I2 Electronics for Medicine. Heart rate, central venous, pulmonary arterial, pulmonary wedge, and aortic pressures, aortic $\mathrm{dp} / \mathrm{dt}$, cardiac output, cardiac index, and stroke output, and pulmonary and systemic vascular resistance were measured or derived.

Renal studies were performed as follows: an indwelling Foley catheter was positioned in the bladder on the morning of the study. After complete emptying of the bladder, urine was collected continuously for 30 to 45 minutes. At the conclusion of each period of drug administration, the bladder was emptied by suprapubic pressure. Blood samples for renal studies were obtained by means of one of the venous catheters. Urine and blood samples were analysed for electrolyte content; urine volume was measured for each period of the drug infusion.

Haemodynamic and renal parameters were recorded under basal conditions 30 to 45 minutes after completion of catheterization procedures. Dobutamine was administered intravenously by the micro-drip technique at infusion rates of $\mathrm{I} \mu \mathrm{g} / \mathrm{kg}$ per min in 5 patients, $2.5 \mu \mathrm{g} / \mathrm{kg}$ per min in 13 patients, $5 \mu \mathrm{g} / \mathrm{kg}$ per min in 14 patients and $10 \mu \mathrm{g} / \mathrm{kg}$ per $\mathrm{min}$ in 5 patients. Increasing doses were used for consecutive periods of 30 minutes each. Randomized dosage was not used so as to allow earlier detection of any untoward effects. Repeat recordings of all parameters were obtained at the end of each dobutamine infusion period. Duplicate readings were all considered in calculating individual parameters. These values were then used for computation of the averages. Statistical analysis and Students paired ' $t$ ' tests for significance were applied to all values obtained.

\section{Results}

The haemodynamic effects of dobutamine are presented for Group A in Table I, and for Group B in Table 2. Fig. 2 to 4 represent individual and average dose-response curves of pertinent parameters for patients in Group B.

In cases with minimal cardiac impairment and clinically 'compensated' (Group A), haemodynamic and renal parameters showed few changes with the dose range indicated in Table $\mathrm{I}$. The inotropic activity of dobutamine, however, was manifested by moderately significant increases in cardiac output and aortic dp/dt, as well as by reduction in pulmonary wedge pressure. In contrast, patients with severe congestive heart failure (Group B) had a most significant and interesting response (Table 2).

\section{Cardiac index (Fig. 2)}

Initially at a low mean value of $2.11 \mathrm{~min}^{-1} \mathrm{~m}^{-2}$ it increased steadily and significantly with progressive doses of the drug to a high normal value of 3.4 $1 \mathrm{~min}^{-1} \mathrm{~m}^{-2}$, representing an increase of 83 per cent above control. This augmentation in cardiac output and index was observed in each individual case.

\section{Stroke volume (Fig. 3)}

This rose concomitantly with cardiac index to 39 per cent over control values, indicating the significant contribution of enhanced contractility upon total output, in the face of a stable preload.

Heart rate (Fig. 4)

This changed comparatively little from a mean control of $86 / \mathrm{min}$ to IOI $/ \mathrm{min}$ at the maximal infusion of $10 \mu \mathrm{g} / \mathrm{kg}$ per min. Though increases in heart 
rate averaged 3I per cent above control, they were not excessive in any individual patient, were well tolerated, and were not associated with ectopic arrhythmias.

\section{Aortic dp/dt}

This increased significantly up to 76 per cent over control values at the infusion rate of $10 \mu \mathrm{g} / \mathrm{kg}$ per $\min$.

\section{Mean aortic pressure}

This remained strikingly stable throughout the study, while calculated systemic vascular resistance fell as a measure of increased cardiac output without significant changes in mean arterial pressure.

\section{Pulmonary wedge pressure}

Pulmonary wedge pressure, obtained in 8 patients, was significantly reduced. All had initial pressures between 15 and $38 \mathrm{mmHg}(2.0-5.1 \mathrm{kPa})$ and there were large falls in 6 patients. The two cases (Cases 9 and 13) without obvious changes had predominant aortic stenosis and mitral stenosis, respectively.

\section{Central venous pressure}

This also fell significantly and progressively for the group, mainly because of a conspicuous reduction in 3 patients from initial values of 15,33 , and $18 \mathrm{~cm} \mathrm{H}_{2} \mathrm{O}$ (I.5, 3.3, and $1.8 \mathrm{kPa}$ ) to 9,25 , and

TABLE I Hacmodynamic effects of dobutamine (Group $A$ )

\begin{tabular}{|c|c|c|c|c|}
\hline & & Basal & $2.5 \mu \mathrm{g} / \mathrm{kg}$ per min & $5 \mu g / k g$ per min \\
\hline $\begin{array}{l}\text { Haemodynamics } \\
\text { Heart rate (beats/min) }\end{array}$ & $\begin{array}{l}\text { Mean } \pm S E \\
\text { Per cent } \\
\mathbf{P}\end{array}$ & $\begin{array}{l}n=4 \\
69 \pm 1.4 \\
100\end{array}$ & $\begin{array}{l}n=4 \\
65 \pm 1.6 \\
94 \\
N S\end{array}$ & $\begin{array}{l}\mathrm{n}=4 \\
77 \pm 3.2 \\
\text { II I } \\
\text { NS }\end{array}$ \\
\hline Cardiac output (1/min) & $\begin{array}{l}\text { Mean } \pm S E \\
\text { Per cent } \\
P\end{array}$ & 100 & $\begin{array}{l}7.2 \pm 0.90 \\
\text { II6 } \\
\text { NS }\end{array}$ & $\begin{array}{l}7.2 \pm 0.42 \\
\mathrm{I} 16 \\
0.02\end{array}$ \\
\hline Cardiac index $\left(1 \min ^{-1} \mathrm{~m}^{-2}\right)$ & $\begin{array}{l}\text { Mean } \pm S E \\
\text { Per cent } \\
P\end{array}$ & 100 & $\begin{array}{l}4.0 \pm 0.36 \\
\text { II } 4 \\
\text { NS }\end{array}$ & $\begin{array}{l}4.1 \pm 0.70 \\
117 \\
0.05\end{array}$ \\
\hline Stroke volume (ml) & $\begin{array}{l}\text { Mean } \pm S E \\
\text { Per cent } \\
\text { P }\end{array}$ & $\begin{array}{l}89 \pm 9.8 \\
100\end{array}$ & $\begin{array}{l}103 \pm 13 \\
\text { I15 } \\
\text { NS }\end{array}$ & $\begin{array}{l}94 \pm 5.3 \\
\text { IO5 } \\
\text { NS }\end{array}$ \\
\hline Mean aortic pressure $(\mathrm{kPa})$ & $\begin{array}{l}\text { Mean } \pm S E \\
\text { Per cent } \\
P\end{array}$ & $\begin{array}{l}12.9 \pm 1.0 \\
100\end{array}$ & $\begin{array}{l}12.9 \pm 1.3 \\
100 \\
\text { NS }\end{array}$ & $\begin{array}{l}13.6 \pm I .3 \\
\text { I05 } \\
\text { NS }\end{array}$ \\
\hline Aortic dp/dt $(\mathrm{kPa} / \mathrm{s})$ & $\begin{array}{l}\text { Mean } \pm S E \\
\text { Per cent } \\
\text { P }\end{array}$ & $\begin{array}{l}107.4 \pm 18.2 \\
100\end{array}$ & $\begin{array}{l}141.9 \pm 21.3 \\
132 \\
0.001\end{array}$ & $\begin{array}{l}137.3 \pm 10.4 \\
131 \\
0.02\end{array}$ \\
\hline Systemic vascular resistance ( $\left.\mathrm{MPa} \mathrm{s} \mathrm{m}{ }^{-3}\right)$ & $\begin{array}{l}\text { Mean } \pm S E \\
\text { Per cent } \\
P\end{array}$ & $\begin{array}{l}127.8 \pm 7.99 \\
100\end{array}$ & $\begin{array}{l}111.2 \pm 16.8 \\
88 \\
\text { NS }\end{array}$ & $\begin{array}{l}\text { III.9 } \pm 10.4 \\
88 \\
\text { NS }\end{array}$ \\
\hline Pulmonary wedge pressure $(\mathrm{kPa})$ & $\begin{array}{l}\text { Mean } \pm S E \\
\text { Per cent } \\
\mathbf{P}\end{array}$ & $100^{1.5 \pm 0.1}$ & $\begin{array}{l}1.2 \pm 0.09 \\
80 \\
N S\end{array}$ & $\begin{array}{l}0.5 \pm 0.09 \\
38 \\
0.001\end{array}$ \\
\hline Mean pulmonary artery pressure $(\mathrm{kPa})$ & $\begin{array}{l}\text { Mean } \pm S E \\
\text { Per cent } \\
P\end{array}$ & $100^{2.3 \pm 0.6}$ & $\begin{array}{l}1.9 \pm 0.5 \\
82 \\
\text { NS }\end{array}$ & $\begin{array}{l}1.6 \pm 0.4 \\
70 \\
\text { NS }\end{array}$ \\
\hline Pulmonary vascular resistance $\left(\mathrm{MPa} \mathrm{s} \mathrm{m} \mathrm{m}^{-3}\right)$ & $\begin{array}{l}\text { Mean } \pm S E \\
\text { Per cent } \\
P\end{array}$ & $\begin{array}{l}11.2 \pm 2.9 \\
100\end{array}$ & $\begin{array}{l}9.6 \pm 1.9 \\
84^{2} \\
\text { NS }\end{array}$ & $\begin{array}{l}8.8 \pm 0.9 \\
83 \\
\text { NS }\end{array}$ \\
\hline Central venous pressure $(\mathrm{kPa})$ & $\begin{array}{l}\text { Mean } \pm \text { SE } \\
\text { Per cent } \\
P\end{array}$ & ${ }_{100}^{0.46 \pm 0.37}$ & $\begin{array}{l}0.30 \pm 0.17 \\
67 \\
\text { NS }\end{array}$ & $\begin{array}{l}0.21 \pm 0.1 \\
45 \\
\text { NS }\end{array}$ \\
\hline
\end{tabular}

Conversion factor SI Units to Traditional Units: I kPa $\approx 7.5 \mathrm{mmHg} ; \mathrm{I} \mathrm{kPa} \approx 10 \mathrm{~cm} \mathrm{H}_{2} \mathrm{O} ; \mathrm{I} \mathrm{MPa} \mathrm{s} \mathrm{m}^{-3} \approx 0.125$ arbitrary units of resistance. 
Io $\mathrm{cm} \mathrm{H}_{2} \mathrm{O}(0.9,2.5$, and $\mathrm{I} .0 \mathrm{kPa})$, respectively, at the end of the study period.

\section{Mean pulmonary artery pressure}

This remained essentially stable, while calculated pulmonary vascular resistance dropped significantly at the infusion rate of $10 \mu \mathrm{g} / \mathrm{kg}$ per min.

\section{Urine flow}

This was measured in 7 patients (Group B) and increased from an average control value of $0.7 \pm$ $0.18 \mathrm{ml} / \mathrm{min}$ to $2.3 \pm \mathrm{I} .5$ at an infusion rate of $10 \mu \mathrm{g} /$ kg per min.

\section{Sodium excretion}

This was also measured in 7 patients (Group B) and increased from a control of $5.7 \pm 1.8 \mathrm{mmol} / \mathrm{min} \times$ $10^{-2}$ to an average of $19.6 \pm 3.7$ at the higher infusion rate. No statistical significance was achieved, however, because of wide variation of these renal parameters and the small number of patients involved.

No side effects were observed in the patients studied.

\section{Discussion}

Catecholamine agents have been used for their vasoactive and inotropic properties particularly in the setting of cardiogenic shock. Our interest has centered rather on their use in conditions associated with congestive heart failure, as an alternative or in addition to glycosides. The short-term intravenous

TABLE 2 Haemodynamic effects of dobutamine (Group B)

\begin{tabular}{|c|c|c|c|c|c|}
\hline & & Basal & $2.5(\mu \mathrm{g} / \mathrm{kg}$ per min $)$ & $5(\mu g / k g$ per min $)$ & IO $(\mu \mathrm{g} / \mathrm{kg}$ per min) \\
\hline \multirow{3}{*}{$\begin{array}{l}\text { Haemodynamics } \\
\text { Heart rate (beats/min) }\end{array}$} & & $n=10$ & $\mathrm{n}=9$ & $\mathrm{n}=\mathrm{I0}$ & $\mathrm{n}=5$ \\
\hline & Mean $\pm S E$ & $86 \pm 4.6$ & $90 \pm 4.9$ & $95 \pm 5.1$ & IOI \pm 4.2 \\
\hline & $\begin{array}{l}\text { Per cent } \\
\mathbf{P}\end{array}$ & 100 & $\begin{array}{l}\text { I04 } \\
\text { NS }\end{array}$ & $\begin{array}{l}\text { IIO } \\
\text { NS }\end{array}$ & $\begin{array}{l}131 \\
0.001\end{array}$ \\
\hline \multirow[t]{2}{*}{ Cardiac output (1/min) } & Mean \pm SE & $3.7 \pm 0.22$ & $4.7 \pm 0.33$ & $5.2 \pm 0.22$ & $6.4 \pm 0.45$ \\
\hline & $\begin{array}{l}\text { Per cent } \\
P\end{array}$ & 100 & 127 & 140 & 182 \\
\hline \multirow{2}{*}{$\begin{array}{l}\text { Cardiac index } \\
\qquad\left(1 \mathrm{~min}^{-1} \mathrm{~m}^{-2}\right)\end{array}$} & Mean $\pm S E$ & $2.1 \pm 0.16$ & $\begin{array}{l}0.01 \\
2.6+0.24\end{array}$ & $\begin{array}{l}0.001 \\
2.9 \pm 0.16\end{array}$ & $\begin{array}{l}0.01 \\
3.4 \pm 0.25\end{array}$ \\
\hline & Per cent & 100 & $\begin{array}{l}123 \\
\text { NS }\end{array}$ & $\begin{array}{l}2.9 \pm 0.10 \\
138 \\
0.001\end{array}$ & $\begin{array}{l}3.4 \pm 0.25 \\
183 \\
0.001\end{array}$ \\
\hline \multirow[t]{2}{*}{ Stroke volume (ml) } & Mean \pm SE & $44 \pm 3.2$ & $53 \pm 4.5$ & $55 \pm 3.4$ & $64 \pm 4.1$ \\
\hline & $\begin{array}{l}\text { Per cent } \\
\mathbf{P}\end{array}$ & 100 & & & $\begin{array}{l}139 \\
0.01\end{array}$ \\
\hline \multirow[t]{2}{*}{ Mean aortic pressure $(\mathrm{kPa})$} & Mean $\pm S E$ & $12.1 \pm 0.8$ & $12.4 \pm 0.6$ & $12.4 \pm 0.6$ & $12.6 \pm 1.0$ \\
\hline & $\begin{array}{l}\text { Per cent } \\
\text { P }\end{array}$ & 100 & $\begin{array}{l}\text { IO2 } \\
\text { NS }\end{array}$ & $\begin{array}{l}\text { IO2 } \\
\text { NS }\end{array}$ & $\begin{array}{l}\text { Ioo } \\
\text { NS }\end{array}$ \\
\hline \multirow[t]{2}{*}{ Aortic dp/dt (kPa/s) } & Mean \pm SE & $92.0 \pm 13.7$ & $118.4 \pm 22.6$ & $142.9 \pm 29.3$ & $188.1 \pm 53.2$ \\
\hline & $\begin{array}{l}\text { Per cent } \\
\mathbf{P}\end{array}$ & 100 & & $\begin{array}{l}155 \\
0.02\end{array}$ & $\begin{array}{l}176 \\
0.02\end{array}$ \\
\hline \multirow{2}{*}{$\begin{array}{l}\text { Systemic vascular } \\
\quad \text { resistance }\left(\mathrm{MPa} \mathrm{s} \mathrm{m} \mathrm{m}^{-3}\right)\end{array}$} & Mean $\pm S E$ & $199.7 \pm 12.8$ & $159.8 \pm 12.8$ & $135.8 \pm 9.6$ & $119.8 \pm 13.6$ \\
\hline & Per cent & 100 & 80 & 08 & \\
\hline \multirow{2}{*}{$\begin{array}{l}\text { Pulmonary wedge pressure } \\
(\mathrm{kPa})\end{array}$} & Mean $\pm S E$ & $3.2 \pm 0.4$ & $2.5 \pm 0.4$ & $2.2 \pm 0.4$ & $1.9 \pm 0.5$ \\
\hline & $\begin{array}{l}\text { Per cent } \\
\mathbf{P}\end{array}$ & 100 & $\begin{array}{l}79 \\
\text { NS }\end{array}$ & & \\
\hline $\begin{array}{l}\text { Mean pulmonary artery } \\
\text { pressure }(\mathrm{kPa})\end{array}$ & $\begin{array}{l}\text { Mean } \pm \text { SE } \\
\text { Per cent } \\
\text { P }\end{array}$ & 100 & $\begin{array}{l}4.0 \pm 0.7 \\
\text { I03 } \\
\text { NS }\end{array}$ & $\begin{array}{l}86^{3 \cdot 3 \pm 0.6} \\
\text { NS }\end{array}$ & $\begin{array}{l}3.7 \pm 1.0 \\
86^{3 S}\end{array}$ \\
\hline $\begin{array}{l}\text { Pulmonary vascular } \\
\quad \text { resistance }\left(\mathrm{MPa} \mathrm{s} \mathrm{m} \mathrm{m}^{-3}\right)\end{array}$ & $\begin{array}{l}\text { Mean } \pm S E \\
\text { Per cent } \\
\text { P }\end{array}$ & $\begin{array}{l}19.9 \pm 3.8 \\
100\end{array}$ & $\begin{array}{l}23.2 \pm 6.8 \\
116 \\
\text { NS }\end{array}$ & $\begin{array}{l}18.4 \pm 4.7 \\
92 \\
\text { NS }\end{array}$ & $\begin{array}{l}15.2 \pm 5.6 \\
84 \\
0.001\end{array}$ \\
\hline $\begin{array}{l}\text { Central venous pressure } \\
(\mathrm{kPa})\end{array}$ & $\begin{array}{l}\text { Mean } \pm S E \\
\text { Per cent } \\
P\end{array}$ & 100 & $\begin{array}{l}0.85 \pm 0.3 \\
85 \\
0.02\end{array}$ & $\begin{array}{l}0.69 \pm 0.24 \\
69 \\
0.01\end{array}$ & $\begin{array}{l}0.64 \pm 0.19 \\
65 \\
0.05\end{array}$ \\
\hline
\end{tabular}

Conversion from SI Units to Traditional Units: $\mathrm{I} \mathrm{kPa} \approx 7.5 \mathrm{mmHg}: \mathrm{I} \mathrm{kPa} \approx \mathrm{IO} \mathrm{cm} . \mathrm{H}_{2} \mathrm{O}$; $\mathrm{MPa} \mathrm{s} \mathrm{m}^{-3} \approx 0.125$ arbitrary units of resistance.

For the 5 patients receiving the dose of $10 \mu \mathrm{g} / \mathrm{kg}$ per min, per cent change and $\mathbf{P}$ values were calculated against their own control at a basal state. 


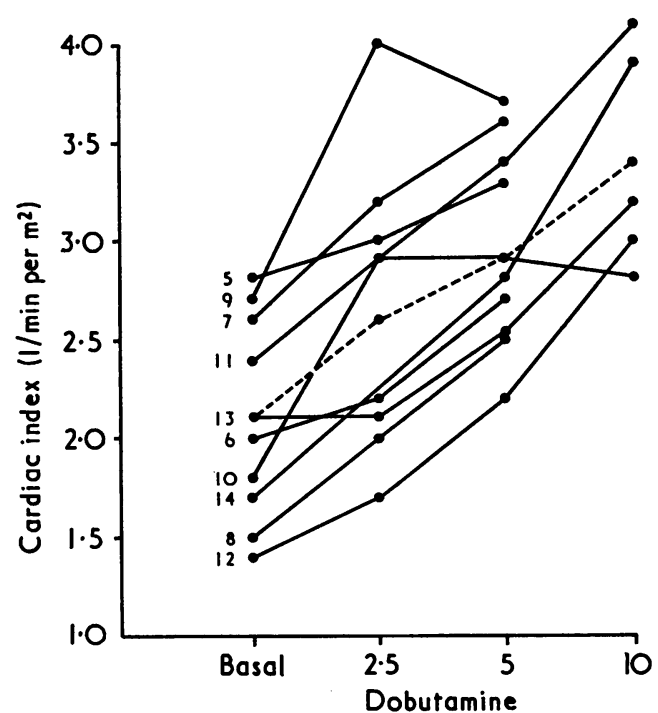

FIG. 2 Dose-related effects of dobutamine on cardiac index. In this and subsequent Figs, only patients in Group $B$ are considered. Individual patients are numbered and represented by continuous lines. The mean values for the group are represented by a broken line. Doses of dobutamine are in $\mu \mathrm{g} / \mathrm{kg}$ per min.

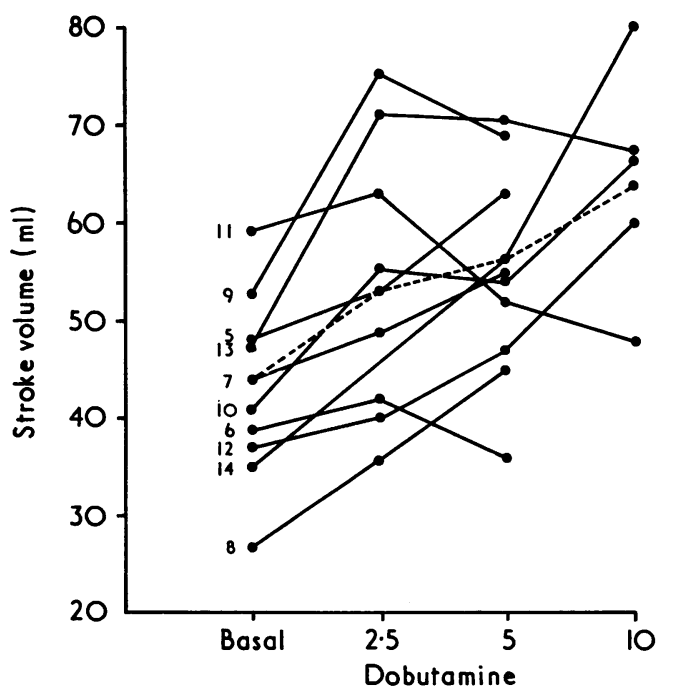

FIG. 3 Dose-related effects of dobutamine on stroke volume.

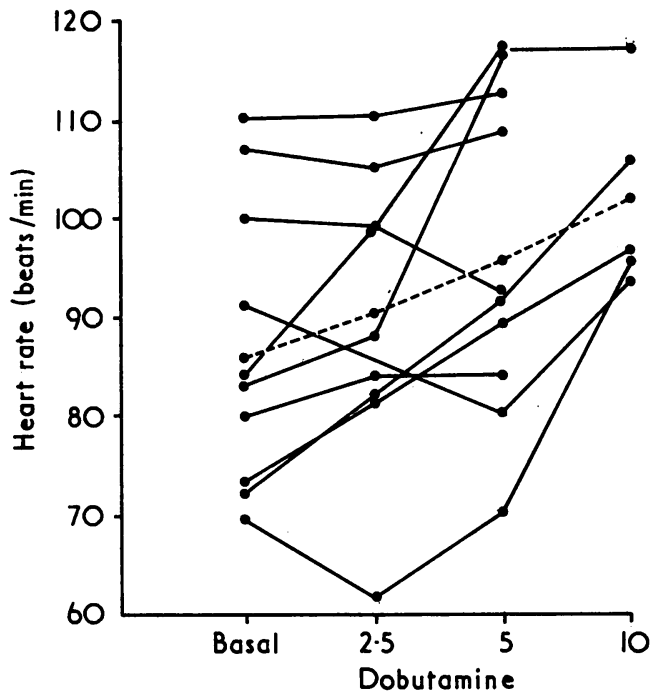

FIG. 4 Dose-related effects of dobutamine on heart rate.

administration of catecholamines has proved effective in improving haemodynamic parameters of cardiac contractility in patients with acute myocardial infarction (Beregovich et al., 1972), after cardiac surgery (Beregovich et al., 1971), and in severe, chronic, or unresponsive heart failure (Beregovich et al., 1974). Unfortunately these agents, including isoprenaline and dopamine, may induce inordinate tachycardia or arrhythmias and might be deleterious at high doses in myocardial infarction (Maroko et al., 1971).

The pharmacological and experimental observations of Tuttle and Mills (in press) in their efforts to develop a new inotropic agent, dobutamine, have demonstrated its lesser chronotropic and arrhythmogenic effect. Furthermore, in animals with myocardial infarction induced by coronary ligation, dobutamine seemed to contain the area of infarction by improvement of coronary blood flow relative to myocardial oxygen demand (Tuttle et al., 1973).

In this investigation, we have studied the haemodynamic and renal effects of dobutamine in a group of patients with different degrees of chronic heart failure. Progressive increments in the dose were used in order to outline dose-response curves and to assess the most effective dose range for clinical administration.

Patients without significant cardiac failure (functional class II) showed little response to dobutamine, though some parameters of cardiac perform- 
ance, such as cardiac output and aortic dp/dt did increase. It should be recognized, however, that aortic $\mathrm{dp} / \mathrm{dt}$, being partly dependent on peripheral vascular factors, is not a strict expression of myocardial contractility. On the other hand, patients with severe and chronic cardiac failure (functional class III and IV) showed significant improvement in their overall cardiac performance. In this particular group cardiac output increased by 82 per cent, cardiac index 83 per cent, stroke volume 39 per cent, and aortic dp/dt 76 per cent from control values. This response was achieved with only $3 \mathrm{I}$ per cent increase in heart rate and without tachycardia or arrhythmias. While mean aortic and pulmonary pressures remained stable, significant reductions of calculated vascular resistances and venous filling pressures were observed.

The most effective dose range in achieving the described results was 5 to $10 \mu \mathrm{g} / \mathrm{kg}$ per min. A dose of $\mathrm{I} \mu \mathrm{g} / \mathrm{kg}$ per min used initially in 5 patients produced no effect and was subsequently abandoned. The dose of $10 \mu \mathrm{g} / \mathrm{kg}$ per min was used only in 5 patients of Group B, towards the end of this study, and once adequate tolerance had been shown to lower dosage. Doses higher than $10 \mu \mathrm{g} / \mathrm{kg}$ per min, though not explored in the present investigation, might be limited by further increases in heart rate

Dobutamine has proved to be a powerful inotropic agent in the context of clinical congestive heart failure, devoid of untoward side effects within the dose range used in this investigation. Longer periods of administration would be a logical next step in further evaluation of this drug.
Dobutamine used in this investigation was supplied by Eli Lilly and Company.

We are grateful to Dr. A. F. Fasola, and Dr. R. R. Tuttle from the Lilly Research Laboratories, for advice in planning this investigation.

\section{References}

Beregovich, J., Bianchi, C., Rubler, S., Lomnitz, E., Cagin, N., and Levitt, B. (1974). Dose-related hemodynamic and renal effects of dopamine in congestive heart failure. American Heart fournal, 87, 550.

Beregovich, J., Reicher-Reiss, H., and Grishman, A. (1972). Haemodynamic effects of isoprenaline in acute myocardial infarction. British Heart fournal, 34, 705.

Beregovich, J., Reicher-Reiss, H., Kunstadt, D., and Grishman, A. (197I). Hemodynamic effects of isoproterenol in cardiac surgery. Fournal of Thoracic and Cardiovascular Surgery, 62, 957.

McDonald, R. H., Goldberg, L. I., McNay, J. L., and Tuttle, E. P. (1964). Effects of dopamine in man: augmentation of sodium excretion, glomerular filtration rate, and renal plasma flow. Fournal of Clinical Investigation, 43, I I I6.

Maroko, P. R., Kjekshus, J. K., Sobel, B. E., Watanabe, T., Covell, J. W., Ross, J., and Braunwald, E. (I97I). Factors influencing infarct size following experimental coronary artery occlusions. Circulation, 43, 67.

Rosenblum, R., Tai, A. R., and Lawson, D. (1970). Cardiac and renal haemodynamic effects of dopamine in man. Clinical Research, 18, 326.

Seldinger, S. I. (1953). Catheter replacement of the needle in percutaneous arteriography. Acta Radiologica, 39, 368.

Tuttle, R. R., and Mills, J. (1971). Dobutamine: development of a new catecholamine to selectively increase cardiac contractility. Circulation Research. In the press.

Tuttle, R. R., Pollock, G. D., Todd, G., and Tust, R. (1973). Dobutamine: containment of myocardial infarction size by a new inotropic agent (abstract). Circulation, 48, Suppl. IV, 132.

Requests for reprints to Dr. Jonas Beregovich, I I I East 85th Street, New York, N.Y. I0028, U.S.A. 